\title{
Sodium-Dependent Noradrenaline Transporter
}

National Cancer Institute

\section{Source}

National Cancer Institute. Sodium-Dependent Noradrenaline Transporter. NCI

Thesaurus. Code C117244.

Sodium-dependent noradrenaline transporter (617 aa, $\sim 69 \mathrm{kDa}$ ) is encoded by the human

SLC6A2 gene. This protein plays a role in the reuptake of norepinephrine by presynaptic cells. 